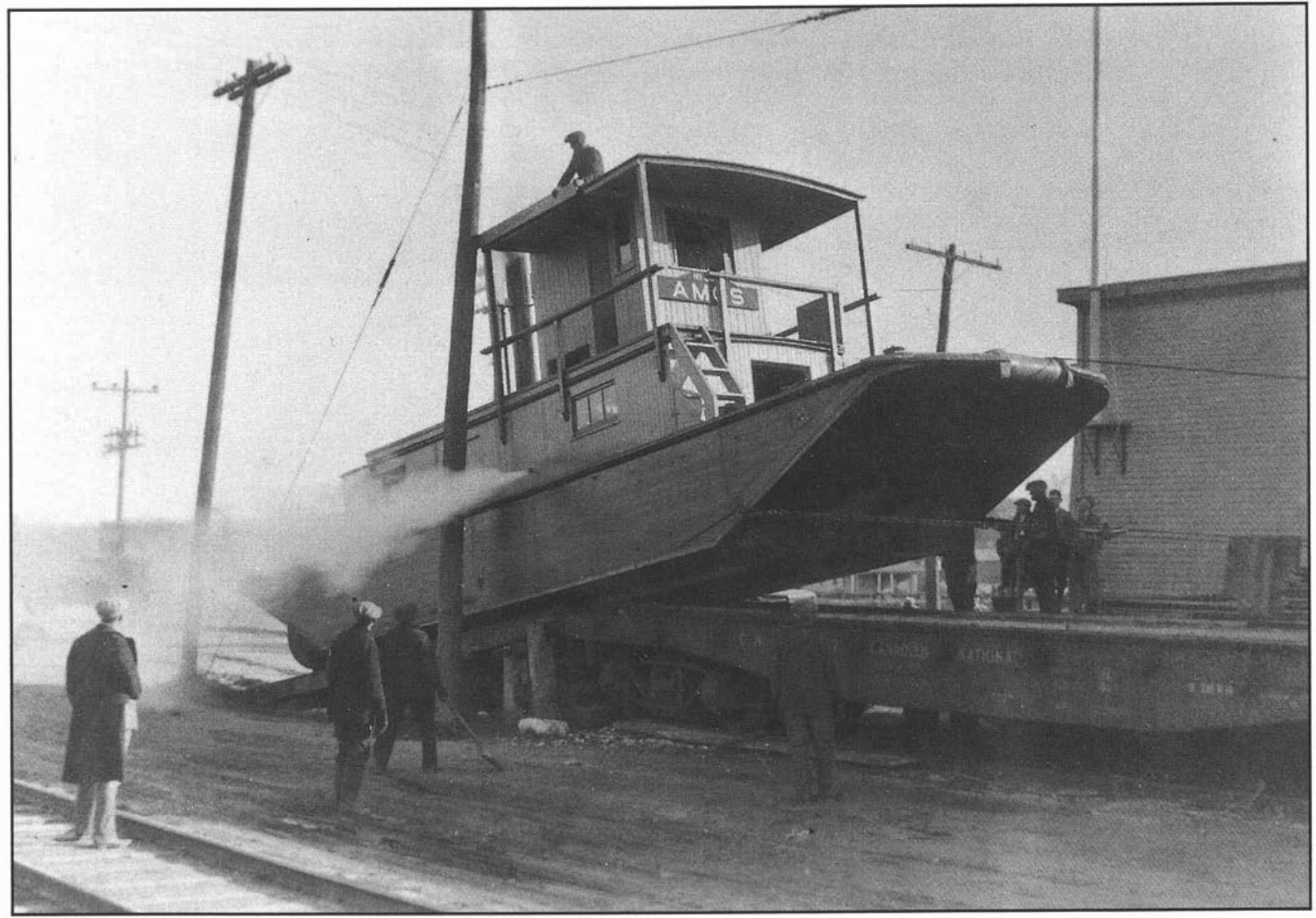

\title{
The Alligator Steam Warping Tug
}

\author{
by Clarence F. Coons, R.P.F.
}

John Ceburn West of Simcoe Ontario invented the Alligator Steam Warping Tug in 1889. This unique craft could travel both on water and land . Because of this, it soon acquired the name "Alligator".

The Alligator was a steam powered warping tug, a craft designed primarily to move sawlogs and later used to move pulpwood through chains of inland lakes to main rivers, where the river log drives commenced.

John West and his partner James Peachey manufactured Alligators in their factory at Simcoe. They sold them to many of Canada's great timber barons and lumbermen, particularly those operating in Ontario and Quebec. A few Alligators went to buyers in other Canadian provinces as well as the

Clarence Coons is an avid forest historian who has spent many years researching the history of the West and Peachey Steam Warping Tug.

This article was prepared from information contained in an extensive manuscript he is preparing for publication. Anyone with interesting facts or photos on the tugs should contact Clarence at R.R.5, Kemptville, Ontario. KOG 1JO, or the Norfolk Historical Society, 109 Norfolk St. South, Simcoe, Ontario. N3Y $2 W 3$.
United States and South America. During the period of their production, (1889-1934) a total of 207 were manufactured.

The Alligator was described by its builders as capable of carrying out several worthwhile jobs for lumberman and mill owners. They claimed that

it will climb hills and go through swamps or woods or up small streams from one lake to another. After warping a boom of logs it will return with the empty boom doing the work cheaply and thoroughly with a great saving of time and number of men.

It was truly an engineering marvel that greatly reduced the cost of getting sawlogs from the inland lake areas. A lumberman, they claimed, could pay for a new Alligator in one year with labour savings alone. It could move up to 60,000 logs at a time in a single bag boom at a speed of about one mile per hour. Only five men were required to operate it and conduct a warping operation.

By the 1880 's, lumbermen were faced with having to go further and further inland from main rivers to acquire good

Newly completed alligators were transported by rail car from Simcoe. This is the Alligator Amos, \#204 shipped April 23, 1929 to Frank Blais and Sons Ltd. Amos, P.Q.

Photo Credit: Eva Brook Donly Museum 


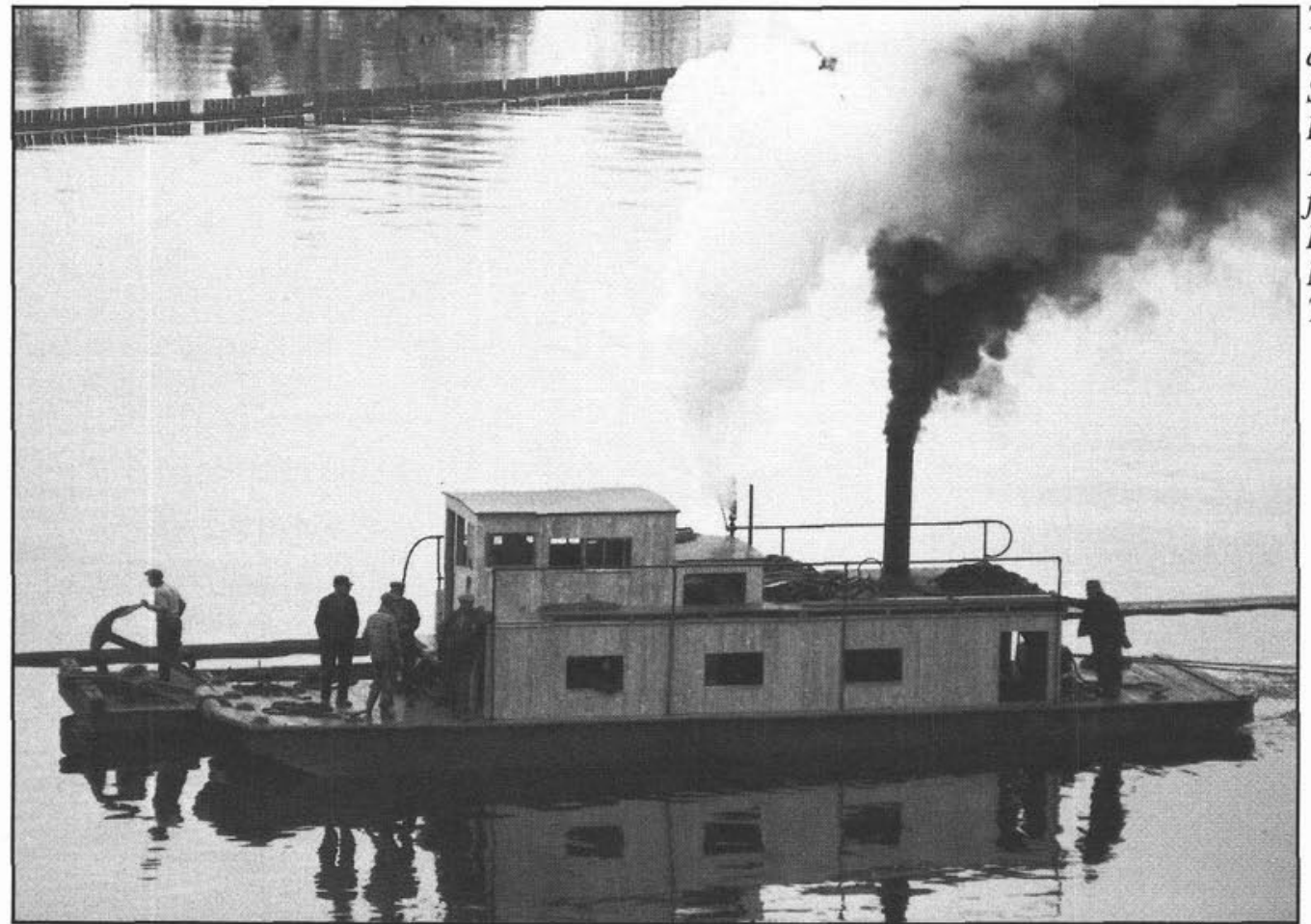

pine timber. The task of moving this timber out through numerous inland lakes to main rivers where it could be driven to sawmills was time consuming, very labour intensive and expensive. There was a great need for the development of mechanized equipment to reduce the hardship men faced in transporting timber, to reduce logging costs and to speed up the delivery of logs to the sawmills.

In the late fall and early winter the trees were cut, bucked into logs, and later in the winter delivered to a lake or lakeshore. On the lake, boom logs were laid out around the logs forming a bag boom. A bag boom was a series of logs or timbers fastened together end to end by short chains known as boom chains. Once filled with logs, the boom was closed by chaining the end logs together. Thus, a bag boom filled with logs was formed. The Alligator moved the boom of logs usually referred to as simply the "boom" by use of it's winch, cable and anchor, in a procedure known as warping.

When it was necessary for the tug to move from one lake to the next, and no navigable stream existed between the two, a portage route through the forest was cleared and the Alligator, by the use of its cable and winch, would skid itself across the portage to the next lake. In the meantime, the boom would be opened and the logs transferred to the next lake via a small stream, or a flume built to connect the two lakes. On reaching the next lake, the logs were collected in another bag boom and warped down it by the Alligator. This sequence continued until a main river was reached where the logs would be set free to flow with the current down river to the mill in a log drive.

West and Peachey Alligators served their owners well, a fact made clear by the many favourable testimonials they received.

The following testimonial from a satisfied customer was typical of Alligator owners approval of them.
The last operational West and Peachey Alligator, the St. Maurice \#5 at Three Rivers, Quebec in May 1962. Its last run was in the fall of 1967.

Photo Credit: National Museum of Science and Technology

Ottawa, Ontario

Messrs. West and Peachey

Sept. 22, 1893

Simcoe, Ontario

Gentlemen,

It gives me great pleasure to say from our experience with the Alligator Steam Warping Tug purchased from you this spring, ("North River") that it has proved a great success doing much more valuable work than anything you represented or we expected. We consider we saved the price of the tug in the past seasons operations.

Yours respectfully, Shepard and Morse Lumber Co. per Peter Whelan.

\section{Pine to Build a Nation}

The vast pine forests of the Canadian Shield in Ontario and Quebec provided the work place for most of West and Peachey's Alligators. The largest number of Alligators went to the Ottawa Watershed where it is estimated that 35-40 percent of them operated. Other areas where West and Peachey alligators concentrated were the waters leading into Georgian Bay and the north shore of Lake Huron as well as the Lake of the Woods-Rainy Lakes District of Northwestern Ontario, the Trent Watershed in central Ontario, and the Saguenay and St. Maurice River Watersheds in Quebec.

The principal tree species harvested in eastern Canada during the nineteenth century were white and red pine. White pine, the monarch of our eastern Canadian forests, far surpassed other eastern North American tree species in size, sometimes reaching a height of 175 feet and a diameter at breast height of six feet. Trees were often found having diameters between 2 and $3 \frac{1}{2}$ feet and 100 feet tall. Some of the largest white pine trees contained between five and six thousand board feet of lumber and deals when sawn. White pine often grew in pure stands where volumes 


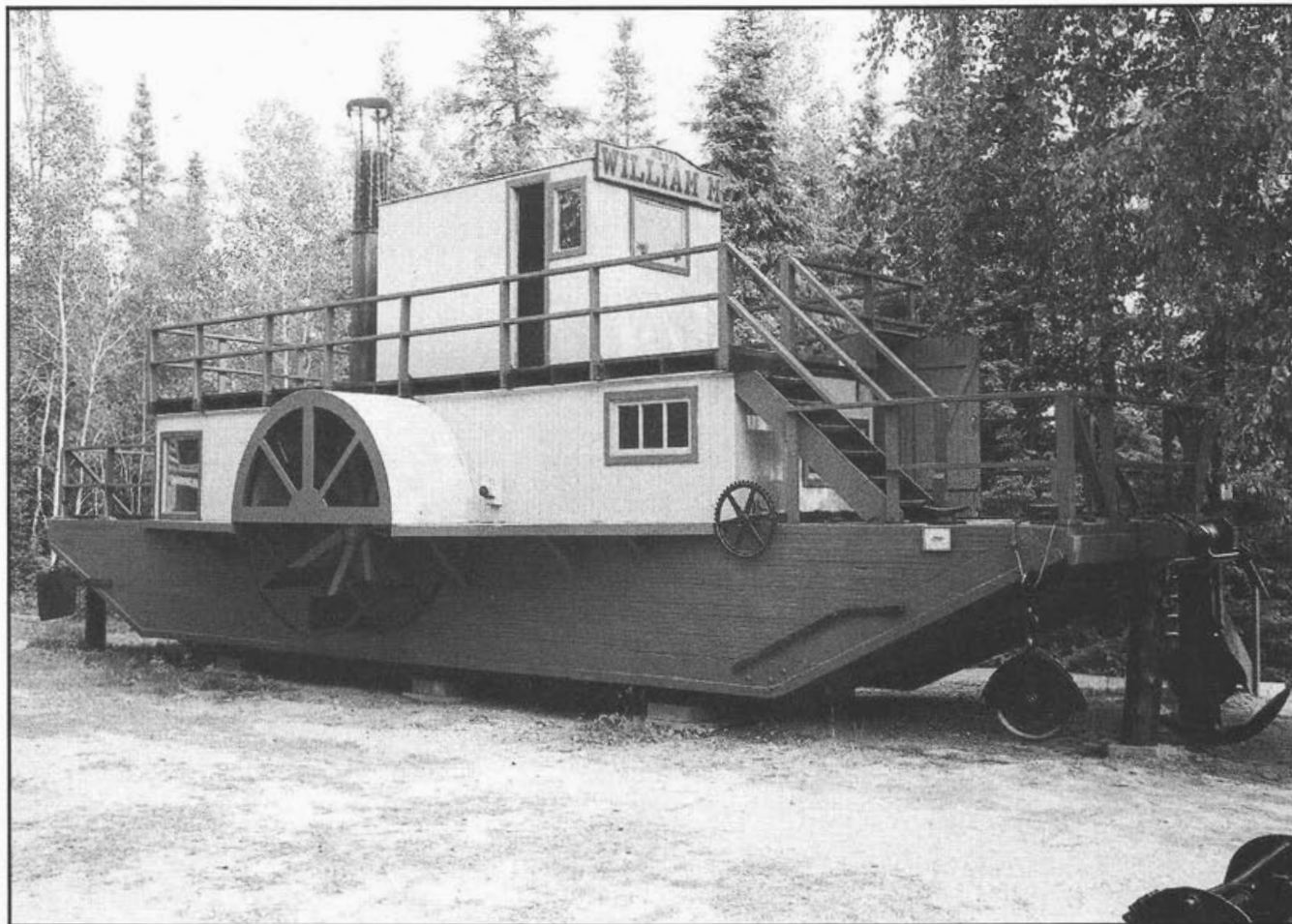

Alligator \#171 William M. Last used by Gillies Bros. Lumber Co. on Cedar Lake in Algonquin Park in 1946. In 1959 it was removed to the Algonquin Park Pioneer Logging Exhibit. During the winter of 1991-92 it was relocated to the new Algonquin Logging Museum on Clarke Creek near the east gate of the Park.

Photo Credit: Ontario Ministry of Natural Resources

sometimes exceeded 50,000 board feet per acre. In some oldgrowth stands of virgin white pine, the volume reached 100,000 board feet per acre.

Red pine also grew in eastern Canada but less profusely than white pine. Not as large as white pine, this species was found growing to heights of 100 feet and 2-3 feet in diameter. It could also be found growing in mixed stands with white pine and hardwoods.

Timbering in Canada as an important industry began as a result of the issuance of Napoleons' "Berlin Decree" in 1806 which cut off Britain's import of timber from the Baltic and forced Britain to look to British North America for suppliers. In 1807, the first raft of timber was brought down the Ottawa River by Philomen Wright of Hull, Quebec and exported from Quebec City to Britain. Square timber was the principal form in which pine was exported during the first half of the nineteenth century.

About 1850, export markets for Canadian pine lumber began to develop in the United States. The adoption of the Reciprocity Treaty in 1854 allowing free exchange of natural products between Canada and United States including "timber and lumber of all kinds, round, hewn and sawn, manufactured in whole or in part" further stimulated this market.

Large sawmills were set up to produce pine lumber and deals for the expanding market. It was then that famous lumbermen like J.R. Booth of Ottawa, Ontario and E.B. Eddy of Hull, Quebec got started in business.

During the next fifty years, hundreds of entrepreneurs gambled their future, buying timber cutting rights and setting up costly sawmills. West and Peachey dealt with many of them. Among them were some of Canada's wealthiest 19th century businessmen including, J.R. Booth, W.C. Edwards, E.B. Eddy, James McLaren, J.J. McFadden, the Klock Bros., the McLachlin Bros., the Gillies Bros., the Gilmours and the Rathbuns, to name a few. While some became wealthy, dozens went bankrupt in a competitive market which fluctuated in concert with the economy of the day. The extensive sawmilling industry which thrived on virgin white and red pine would be largely exhausted by 1920 . Timbering had begun to shift by the turn of the century to the production of pulpwood for the fledgling pulp and paper industry, thus enabling the use of smaller timber and other species like spruce.

\section{Alligator Components and Construction}

The Alligator was manufactured in three sizes. The standard, large and the small or baby. Initially the Standard Alligator was 37 feet in length with a 10 foot beam while the large model was 45 feet in length with an 11 foot beam. The small or baby Alligator introduced in 1907 was 37 feet long with an 8 foot beam.

The hull was built shaped like a scow. The botton was white oak plank 3 inches thick, while the sides were white pine 6 inches wide laid flat and held together with $5 / 8$ inch bolts running from top to bottom on each side. On the bottom of the hull were two white oak runners which were placed 6 feet apart, each runner being $6 \times 8$ inches, shod with $3 / 8$ inch $\times 8$ inch steel or iron. Part of the bottom and the bow of the boat was covered with steel boiler plate.

The first 66 Alligators manufactured were all driven by paddlewheels. In 1904 West and Peachey built their first new type Alligator propelled by twin screws. It was sold to the Federal Department of Public Works in Ottawa for use in operations on the St. Maurice River in Quebec in the spring of 1905. A major advantage of the new twin screw Alligator was that the standard size tug required only a 10 foot space for portaging or passing through floating logs whereas the paddlewheel type required 16 feet.

Alligator boilers were manufactured at the Waterous 


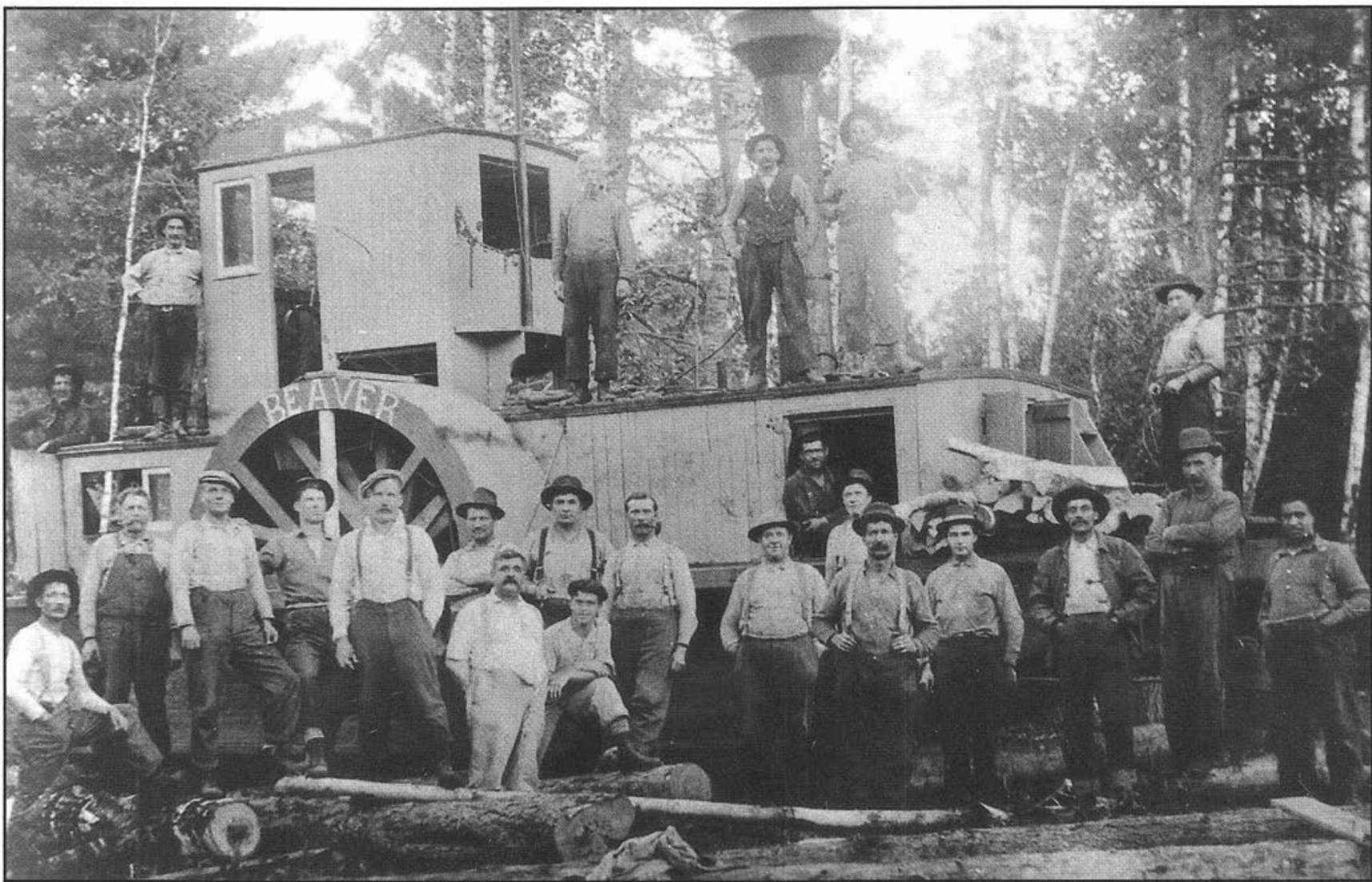

The Alligator "Beaver" \#61 owned by the Rat Portage Lumber Company of Rat Portage Ontario shown crossing a portage through dense north western Ontario forest.

Photo Credit: Fort Frances Museum.

Engine Works in Brantford. Most Alligators used Clyde Marine Boilers. They were return flue boilers, containing a large central furnace flue and many small diameter return flues. A distinguishing feature of these boilers was the fact that they were often mounted on trunnions which by adjustment of a screw jack enabled the fireman to keep the boiler level when crossing steep portages. The standard size boiler was 48 inches in diameter, and 72 inches long and was rated at 22 horsepower.

West and Peachey alligators were equipped with upright single cylinder steam engines manufactured at their Simcoe Factory. Engines were available in three sizes. The standard size engine had a 9 inch bore and stroke.

Each Alligator was equipped with a powerful winch and cable winding device. The first new automatic cable winding device was installed on paddlewheel Alligator \#51 D. Lunam in November 1902. The winch was driven by the Alligators steam engine.

For warping, each Alligator used a long steel cable referred to as the warping rope. The standard size Alligator used a $5 / 8$ inch diameter rope usually 5000 feet in length. The wire rope was cast steel. It was supplied to West and Peachey by the B. Greening Wire Company of Hamilton.

Each Alligator was also equipped with a large cast malleable iron warping anchor. The standard lumberman's warping anchor weighed 500 pounds. These anchors had a long shank, a wide stock and large flukes. The success or failure of warping operations often depended on getting a good hold on the lake bottom. They worked well in lakes with clay bottoms, but could give problems in loose sandy materials.

\section{Tributes to the Old Steam Alligators}

It was at Three Rivers Quebec in the fall of 1967 that the last West and Peachey Alligator was retired from service. As the water cooled in the boiler of St. Maurice \#5, a nostalgic link with the past was severed. For 78 years West and Peachey Alligators had served the lumberman of this nation.

In a fitting tribute to the remarkable Alligator Steam Warping Tug, the Ontario Heritage Foundation erected a historical plaque at the site of the West and Peachey Factory on October 24th, 1982. The unveiling was carried out by descendants of both West and Peachey. Also in memory of the alligator the town named the street behind the site of the old factory "Alligator Lane".

Excellent examples of steam Alligators are on display at the Logging Museum near the east gate of Algonquin Provincial Park and at Wakami Lake Provincial Park near Chapleau.

In 1990, members of the Norfolk Historical Society with the support of the local service organizations brought the weathered remains of a Twin Screw Alligator back to Simcoe from near the northern Ontario town of Atikokan.

A committee under the direction of Ron Judd is restoring the Alligator which will likely be placed on display in the town park near the site of the West and Peachey factory. 